\title{
Children's Views of the Learning Environment: A Study Exploring the Reggio Emilia Principle of the Environment as the Third Teacher
}

\author{
Kelsey Robson and Sonia Mastrangelo
}

\begin{abstract}
Kelsey Robson, RECE OCT MEd, is a doctoral student in the Faculty of Education at Lakehead University. She began her career as an ECE with the district school board of Niagara in the full-day early learning kindergarten program while completing her bachelor of early childhood education, with a focus on the primary/junior divisions, at Brock University. The focus of her MEd was on the Reggio Emilia approach, and she hopes to travel to Italy to visit the Reggio schools this fall. Her areas of research include early learning environments, play, and the Reggio Emilia approach to education. Email: karobson@lakeheadu.ca
\end{abstract}

Sonia Mastrangelo is an associate professor in the Faculty of Education at Lakehead University Orillia. Dr. Mastrangelo began her career with the Dufferin Peel Catholic district school board in the area of kindergarten and special education. Her areas of research include early learning, developmentally appropriate practice, self-regulation, and autism spectrum disorder. She is co-editor of the International Journal on Holistic Early Learning and Development, and she travels internationally facilitating workshops and conducting clinical work in the area of self-regulation and autism early intervention. Email: smastran@lakeheadu.ca

This research study explored the concept of the environment as the third teacher and how kindergarten children in a school inspired by Reggio Emilia viewed their classroom as a space to help them learn. A qualitative analysis of the research data reveals that children perceive their environment as a space that contributes to their learning and acts as a third teacher in the classroom. In summary, the children in this study described the specific ways they were able to learn with the materials located within the centres of their classroom, the ways they engaged in imaginative or pretend play, making real-life connections and communicating with peers, and the learning that developed through exploration of the documentation on the classroom walls.

Key words: Reggio Emilia; environment as third teacher; kindergarten; early learning; children's views
The early years of life are a time of rapid growth and development (Arseven, 2014), and the positive experiences a child has early in life set the foundation for lifelong learning, behaviour, health, and well-being (Ontario Ministry of Education, The Kindergarten Program, 2016). More specifically, a stimulating learning environment leads to higher levels of thoughtful learning experiences for children, which in turn better prepares them for adulthood (Steglin, 2005). Strong-Wilson and Ellis (2007) explain that "childhood is often the first place where we begin to see and use the environment imaginatively [and where] we can begin to notice how our surroundings can take on a life of their own that contributes to children's learning" (p. 40). Makin (2003) defines the term environment in early education settings as "an aggregate of conditions and influences on learning, including both the physical environment (layout, range of resources, access, and use) and the psycho-social environment (interactions between staff and children, among peers, and between the setting and its wider context of homes and communities)" (p. 327). The environment stimulates our senses and contributes to synaptic brain connections that fuel further growth and multiple learning pathways.

It is well documented that a high-quality, positive environment successfully supports students' learning and their holistic development (Hewes, 2006; Makin, 2003; Shipley, 2008; Sylva et al., 2006). Shenk (2010) supports the idea of high-quality learning environments and explains that "children develop only as the environment demands development" (p. 35). Rinaldi (2001) stresses that, when preparing the school environment, it cannot be copied, only created, as it needs to reflect the children, families, educators, and community encompassing the school. She believes that the learning environment should become more than just a space-it should become a part of 
life, which does not substitute for family but creates a new place for culture. The physical characteristics of an educational environment reflect the educator's philosophical beliefs about how children are regarded and the value put on the process of teaching and learning (Makin, 2003; New, 1998). The Kindergarten Program cites Gandini (1998) who emphasizes the Reggio perspective of the environment as a third teacher in the classroom, next to the adults and children in the room (Ontario Ministry of Education, 2016).

The purpose of this research study was to explore the concept of the environment as a third teacher and how students in a school inspired by Reggio Emilia viewed their classroom and its ability to help them learn. A qualitative phenomenological approach was chosen as the research design for this study in order to give power to the participant's voice - namely, the child. The participants in the study were 16 students from a senior kindergarten classroom. The data was collected using observational field notes, photo elicitation, and photo interviewing with the children. The children served as both researchers and participants in this study, since they selected what they deemed valuable and necessary in the environment to help them learn. Analysis of the research data was done using inductive reasoning.

\section{Using Children's Voice in the Research Process}

As the world continues to evolve and the pace of life accelerates, educators need to be aware of the increasingly diverse population of students in the education system and ensure they are providing education that is responsive to the demands of the 21st century (Cook-Sather, 2002; Ontario Ministry of Education, 2016). As changes and enhancements are made to the approaches used in education, such as the emphasis on child-centered learning approaches and inquiry-based education, one needs to ensure the learning environments provided support these approaches to education. Researchers argue that children's perspectives on the quality of their education are rarely explored, which can be troubling given that children are most directly affected by the education system (CookSather, 2002; Montandon \& Osiek, 1998). By taking the time to work with and listen to children throughout the research process, one is better able to see the world through their eyes, notice what sparks their interest, and develop a holistic understanding of what childhood looks like.

To create learning environments responsive to the 21 st century, researchers and educators need to collaborate with students to ensure their needs are being met. Students feel empowered and motivated to engage in their education when their voices are heard and when they are seen as knowledgeable co-participants and decision makers capable of contributing to discussions related to their learning. A barrier to conducting research with children is their vulnerability. Most children will be excluded or denied participation in research on sensitive topics since they would be exposed to these sensitive elements throughout the research process (Harcourt, Perry, \& Waller, 2011). Greig, Taylor, and MacKay (2012) talk about the benefits and challenges of having children as co-researchers. The benefits of children serving as researchers include a more equitable power balance between adult researchers and young participants, children's possession of insider knowledge about childhood that adults do not have, and the effectiveness of young researchers as role models for their peers (Greig, Taylor, \& MacKay, 2012). Some of the challenges for children as researchers is that their lack of experience could result in discomfort when encountering sensitive issues, they may lack confidence when working with agencies, and they may give poor responses to questionnaires and interviews. Pinter and Zandian (2015) discuss the importance of including children's voice in all aspects of the research process, including keeping them informed about the results of a study and listening to their post hoc interpretations of the research. A reconceptualization of children as powerful social agents is needed (Stephenson, 2009), along with a perspective whereby they "are regarded as experts on their own subjective experience" (Grover, 2004, p. 91). 
There is a growing amount of research stressing the importance of children's voice in the research process (Grover, 2004; Lansdown, 2004, 2011; Schiller \& Einarsdottir, 2009), as well as including their perspectives on their education (Cook-Sather, 2002; Einarsdottir, 2005; Montandon \& Osiek, 1998; Smith, Duncan, \& Marshall, 2005). Smith, Duncan, and Marshall (2005) explain that children's perspectives are missing in a large amount of psychological and educational research. When educators and researchers take the time to listen to children's perspectives, they are better able to support their learning and development (Cook-Sather, 2002). UNICEF (2014), in a fact sheet about the Convention on the Rights of the Child, interprets Article 12 as follows: "When adults are making decisions that affect children, children have the right to say what they think should happen and have their opinions taken into account" (p. 2). Over the past 15 years, older children have been increasingly involved in research through the work of NGOs, but researchers tend to have less contact with children under the age of 8 (Lansdown, 2004). Lansdown (2004) explains:

The convention extends participation rights to all children capable of expressing a view. It embodies no age restrictions. There is a pressing need, therefore, to explore approaches which address the rights of younger children to participate, and in so doing, to review the culture, attitudes and practices prevailing in those environments where young children spend their time. (p. 4).

Children are important participants in research, but surprisingly few attempts have been made to understand their perspectives on the quality of their education, even though they are the ones most affected by the environments they learn within (Einarsdottir, 2005).

The research emphasizes that engaging learning environments are essential to children's cognitive, physical, social, and emotional development, and that they "allow children to connect concepts and ideas as they create new schema" (Klefstad, 2015, p. 147). As stated in The Kindergarten Program (Ontario Ministry of Education, 2016), "children become more engaged in their learning when the environment is planned and designed in negotiation with the children - that is, when 'the children's voice' is heard in planning the environment and organizing and selecting materials for learning" (p. 32). An environment that values risk, includes multiple reflections of diversity, and includes educators who "observe, document, and reflect on children's engagement with the environment" becomes a partner in learning with the children (Callaghan, 2013, p. 4).

The study described in this article honoured children's voice. It entailed documenting matters that directly affect children. The study also explored children's views about their learning environment in order to develop a deeper understanding of children's perspectives to ascertain whether they viewed their environment as a third teacher. The aim of this research was to unpack how a child's classroom environment can support children's learning by sparking their natural curiosity to explore.

\section{The Reggio Emilia Approach}

In the past decade, the Reggio Emilia approach to learning has significantly influenced the world of early childhood education with its holistic approach to the education of young children (Wexler, 2004). At the end of the second world war, classrooms in Reggio Emilia, Italy, were set up to support highly collaborative partnerships among parents, educators, and children (Edwards, Gandini, \& Forman, 2011). The 12 guiding principles of the Reggio approach to learning are collaboration, the image of the child, environment as a third teacher, relationships, transparency, documentation, pedagogical documentation, provocation, progettazione (term used to describe curriculum), one hundred languages of children, respect, and reciprocity (Fraser, 2012). When considering the holistic development of young children, it is important to understand the interconnectedness of Reggio Emilia's 12 
guiding principles, which collectively provide rich learning experiences and contribute to optimal growth.

Reggio Emilia school settings are well known for their rich environments that foster student learning because they are both aesthetically and intellectually stimulating and also reflect a respect for the rights, interests, and needs of the individuals who use the space (New, 1998). To create a learning space that acts as a third teacher, invitations for learning that do not require teacher intervention are needed. Fraser (2012) notes that "a classroom that is functioning successfully as a third teacher will respond to the children's interests, provide opportunities for children to make their thinking visible and then foster further learning and engagement" (p. 67). Educators in the Reggio approach can spark their students' interest in learning by introducing "provocations" meant to excite students and spark discussion (Strong-Wilson \& Ellis, 2007). Some examples of provocations could be bringing in realistic objects for children to use, positioning small mirrors around the classroom, or placing easels close to windows for natural sunlight and inspiration from the outdoors (Strong-Wilson \& Ellis, 2007).

The Reggio learning environment is unique in how the space is co-created by the students and the educators in the classroom. This collaborative relationship consists of reciprocal exchanges between the children and adults about appropriate adjustments that can be made to ensure optimal growth and learning within the classroom setting (Hewett, 2001). In conversation with Gandini (2011b), Loris Malaguzzi compared the relationship between the teacher and the children to a game of ping pong. He explained that both players need to contribute to the game to allow for optimal growth and learning, otherwise a single player would be unable to participate (Gandini, 2011b).

\section{The Environment as Third Teacher}

The way Reggio Emilia accomplishes a high-quality environment is by considering the environment as the third teacher. The Reggio Emilia approach is built on a socio-constructivist model that views knowledge as constructed through interactions with both people and the environment (Dodd-Nufrio, 2011). In Reggio-inspired schools, the physical environment holds great importance because it reveals a lot about how children are regarded as well as the value assigned to the process of teaching and learning (New, 1998). In a Reggio Emilia setting, the environment is the third teacher, and it is believed that "the spaces that teachers create for children seem to hold enduring memories for them that have a powerful influence on what they value later in life" (Fraser, 2012, p. 112). In Ontario's kindergarten program (Ontario Ministry of Education, 2016), the importance of the learning environment is expressed as follows: “The learning environment is often viewed as 'the third teacher': it can either enhance learning, optimizing students' potential to respond creatively and meaningfully, or detract from it" (p. 29). Callaghan (2013) also reminds us to view children as able communicators, collaborators, and meaning makers who are forming relationships every day with people and materials. Callaghan states that children are "capable of empathy, whimsy, sensitivity and joy" and the classroom should reflect this through "thoughtfully organized, aesthetically rich, open-ended materials that invite children to communicate their ideas in many ways" (p. 2).

Including children in the creation of the classroom setting will help spark their interest and engagement in the play experiences. Furthermore, as Ontario's How Does Learning Happen? states:

Children thrive in indoor and outdoor spaces that invite them to investigate, imagine, think, create, solve problems, and make meaning from their experiences-especially when the spaces contain interesting and complex materials that children can use in many ways. In addition, when the schedule allows for long periods of uninterrupted play, with few transitions, children are calmer and more engaged. When the environment supports children's growing autonomy and independence, challenging behaviours are reduced and educators can focus more fully on observing, interacting, and extending children's learning and development in meaningful ways. 
(Ontario Ministry of Education, 2014, pp. 20-21).

The work of Bronfenbrenner (1979) stresses the importance of considering the environment as more than just an inanimate object, but rather one of bi-directionality, where the child impacts the environment and in turn is impacted by the environment. Therefore, for every action there is a reaction, and it is this constant interplay that allows development to occur (Darragh, 2006). In a kindergarten context, Becker and Mastrangelo (2017) emphasize that the environment should be filled with many play experiences and a focus on the four frames of belonging and contributing, self-regulation and well-being, demonstrating literacy and mathematics behaviors, and problem solving and innovating (from The Kindergarten Program, Ontario Ministry of Education, 2016. Katz's (1987) framework for learning includes four categories that can also be applied to the concept of the environment as third teacher. Darragh (2006) invites us to reflect on these four categories and reveals that childhood environments should support children's learning by (1) providing information for the senses, (2) supporting the unique needs and preferences of children, (3) offering experiences that are content-rich and (4) giving feedback through bidirectional exchanges. When creating an environment that acts as the third teacher, there are eight principles espoused by Fraser (2012) that need to be addressed: aesthetics, active learning, collaboration, transparency, bringing the outdoors in, flexibility, relationship, and reciprocity.

The aesthetics of a Reggio environment come from the amount of detail put into the creation of every aspect of the space. The principle of active learning can be achieved by providing a rich, stimulating environment that offers many choices and provokes children to discover a variety of materials while actively exploring, investigating, and solving problems. Collaboration is achieved by providing opportunities for children to work individually as well as a part of a group with other children and adults. Transparency is achieved through the use of such materials as mirrors, windows, internal glass walls, glass objects, transparent film, large plastic sheets, etc., throughout the space. Transparency can also be used metaphorically to describe the reasoning behind the documentation of children's work on the classroom walls and entranceways of the school. Bringing the outdoors in helps children connect with their roots and build respect for their community by strengthening the children's sense of belonging in their world. Flexibility can be achieved in a Reggio environment by being accommodating and creative with space, time, and materials. Reciprocity is achieved by ensuring the environment is open to change and responsive to the children, parents, and community. Lastly, relationship in the Reggio environment refers to how objects are shown in relation to other materials in the room (Fraser, 2012). When exploring these eight principles of creating an environment that acts as a third teacher, it is essential to understand their interconnectedness within the classroom setting.

\section{Methodology}

The research design chosen for this study was a qualitative phenomenological approach in order to allow the participants to express their understandings without having their thinking altered in any way (Grover, 2004). This qualitative phenomenological research study followed a framework for listening and responding to young children's perspectives called the mosaic approach (Clark, 2007). The mosaic approach was developed with children aged 3 and 4 and aims to contribute to the voice of a child and recognize young children's perspectives of their early childhood environment (Moss \& Clark, 2011). It is a multimethod approach where children and adults work together to use children's photographs in conjunction with conversations and observations to gain a deeper understanding of the children's views (Moss \& Clark, 2011). The process allows children and adults to be involved in making meaning together by giving them both a chance to step back and reflect on their experiences (Moss \& Clark, 2011). The site selected was a Reggio Emilia school in a large city in Ontario to allow for an in-depth analysis of the concept of the environment as third teacher in the classroom setting. The research participants included 
16 female children in the senior kindergarten program at the Reggio-inspired school who were divided into four focus groups.

The study consisted of three visits to the participating classroom where observations and focus groups took place with the children who were the participant researchers in this study. The first visit to the school consisted of a tour of the grounds and the senior kindergarten classroom, where observations and interactions with the children took place. Prior to the photo elicitation process, there was a discussion in each focus group about different areas of the classroom and how they contribute to the children's learning. The students were then given an iPad and asked to photograph five areas of the classroom that help them learn. The data was collected using this photo elicitation process with groups 1 and 2 of the four focus groups. Photo elicitation is a tool used with children whereby they communicate their ideas both visually and verbally on a topic by first taking pictures and then explaining the pictures to support their thoughts (Pyle, 2013). Prior to the second visit, the photographs taken by groups 1 and 2 during their photo elicitation period were printed. During the second visit, these photos taken by groups 1 and 2 were analyzed using photo interviewing analysis in their respective groups. Photo interviewing analysis allows the participants to examine and analyze a set of visual images to construct meaning while the researcher records these descriptive findings as results (Johnson \& Christensen, 2012). The children's photos were laid out on the table and the children discussed the photos, why they took them, and how the things they photographed are important to their learning. During the second visit to the classroom, data was also collected using photo elicitation with the remaining two focus groups, group 3 and 4.

During the third visit to the classroom, groups 3 and 4 analyzed the photos they took using photo interviewing analysis. This time was also used to meet with students who were absent during one of the visits so that they could analyze the photos they took. Each meeting with the focus groups was video recorded on an iPad to allow for a more in-depth analysis at a later date.

\section{Analysis}

The data that was collected in this study came from observational field notes, photo elicitation, and photo interviewing analysis. The video data collected from the photo elicitation and photo interviewing analysis was transcribed. Inductive reasoning was used to analyze all of the available data, which was coded to support the research question Which areas within the classroom do children believe help them learn? How? When coding, the children's photos were separated into categories that they identified during the photo interviewing analysis part of the study. These categories were the different learning centres in their classroom environment and included mathematics, building, communication, art, light, and drama. The transcribed video data was then examined and the pieces of dialogue that described the children's photos were exported and attached to each photo. The data was then mined for common themes that emerged from the children's dialogue.

\section{Results and Discussion}

The objective of this study was to develop an understanding of how children perceive their classroom environment and to identify areas of the classroom that children believe help them learn. To acquire an in-depth understanding of children's views of their classroom and how it helps them learn, the children served as co-researchers in the study. When asked how their classroom helps them to learn, the children chose to photograph the different centres within the room and then explained how each centre might help them to learn. As a result, their responses were coded according to the centres they labelled.

Of the 85 photos, 20 were taken of the math centre, 15 were taken of the communication centre, 15 were taken of 
the building centre, 11 were taken of the art centre, 10 were taken of the light centre, 6 were taken of the drama centre, and the remaining 8 photos were taken of various different spaces in the room, such as the nature centre, the resting station, the learning garden, the reading centre, and the office (see Table 1). Each of the 16 children took between 4 and 7 photos of their room. Since the math centre was emphasized during both the photo elicitation and the photo interviewing analysis, there appeared to be a strong association among the children that the math centre is an area in the classroom that helps them to learn, followed by communication and building, art, light, and drama.

Table 1: Number of Photos Taken at Each Centre

\begin{tabular}{lc}
\hline \multicolumn{1}{c}{ Centre } & $\begin{array}{c}\text { Number of } \\
\text { Photographs Taken }\end{array}$ \\
\hline Math & 20 \\
Communication & 15 \\
Building & 15 \\
Art & 11 \\
Light & 10 \\
Drama & 6 \\
Other & 8 \\
Total: & $\mathbf{8 5}$
\end{tabular}

In most cases, once a learning centre was identified, the children then went on to explain how different materials within that centre aided in their learning. When asked how the math centre helps them to learn, the children talked mainly about the supporting materials in the centre, such as the hundreds chart, puzzles, tools, LEGO, and "balancing stuff." The children in focus group 3 explained how puzzles helped them learn:

Researcher: What is this?

Amy: Math again.

Researcher: What is going on in this picture?

Emma: We can play puzzles.

Nicole: (whispers to Emma) Puzzles, yep.

Researcher: Play puzzles?

Emma: Yeah.

Researcher: And how does that help you learn?

Emma: Helps us learn lots of things and we know which way is the right way.

Amy: It helps you get smart and it helps you learn how to put things together. It's like putting different words together to make sentences, except you are putting different pieces together.

Drew and Rankin (2004) also support the idea of materials enhancing children's learning; they explain that 
"children extend and deepen their understanding through multiple, hands-on experiences with diverse materials" (p. 3). The light centre was another area in the room where the children identified different materials that helped them to learn, such as a light table, $\mathrm{x}$-rays, magnetics, and jewels. The children described how they manipulated the materials to build different "decorations" and "light things." Elizabeth explained how the light table can help you to learn.

Researcher: What about this one?

Elizabeth: This could help you do shapes and stuff if you don't really know.

Researcher: Wow! What's that place called?

Elizabeth: Light. This light table helps you do shapes. It makes a big light because it is really dark in there.

The addition of open-ended materials such as tools, art materials, and blocks in the room enhances learning because they have no predetermined use (Drew, Ohlsen, \& Pichierri, 2000). Drew and Rankin (2004) conclude that "we can learn a lot from children who show a natural affinity for materials, gravitating to them without fear or intimidation" (p. 4).

Imaginative or pretend play was also a concept brought up by most of the children as a way they can learn in their classroom while others did not make a connection between playing and learning. The building centre was an area where the children identified many different pretend play activities that helped them to learn, such as building castles, houses, a boat, or other structures and playing games, like family. In the drama centre, the children talked about how they play family, pretend to be babies, take care of pets, and build forts with friends. In the light centre, the children talked about playing doctor or family doctor. Mandy and Andrea from focus group 1 explained how you can learn through playing in the drama centre.

Andrea: Drama!

Researcher: Why did you take a picture of drama?

Andrea: Because you can dress up and play family.

Mandy: How to be a parent, and how it would work if you were a parent.

Andrea: How to take care of a baby!

Mandy: And how to take care of pets and babies, and how when you're an adult you're not really interested in eating candy and that kind of stuff.

Samuelsson and Carlsson (2008) explain that in the Reggio approach, play is integrated as a dimension of learning. It is interesting to note that when Shannon was asked "Do all of the centres help you to learn?" she responded by separating play and learning.

Researcher: Why did you take that photo?

Shannon: I wanted to take a picture of almost all the centres so I could see if all of them look different or the same.

Researcher: Do all of the centres help you to learn? 
Shannon: Not really all. Light doesn't, and I am in light right now. Usually people play doctor or family doctor. That's why I like it so much, because you get to play so much and not learn.

She explained that not really all of the centres help you to learn, and that she likes the light centre because you get to play doctor and not learn. Although some of the children concurred with Shannon that they are playing and not learning, they actually are learning, but are just separating the two ideas in speech. Samuelsson and Carlsson (2008) explain that "when young children act they do not separate between play and learning, although they separate them in their talk" (p. 626). When asked how reading helps her to learn, Zoe contradicted herself and explained that it doesn't help you learn, it helps you learn how to read.

Researcher: So why did you take a picture of that?

Zoe: Because when you are reading with our teacher and we are reading some stories, it doesn't really help us learn, but it does help us learn to read.

In Kangas's (2010) study asking children to describe their ideal learning environment, the children separated the ideas of playing and learning, and explained that they want to learn math and other subjects in a more "pleasant way." The children in Kangas's (2010) study separated learning into two different categories: traditional learning methods, such as reading books, and learning under play-like conditions, such as studying through games. Pramling Samuelsson \& Johansson (2006) looked at the idea of playing and learning through a child's perspective; they assert that we need to question the idea that play is a concept that belongs to the child while learning is more concerned with teachers. They explain that, for a child, these dimensions may be separated, but not in the teacher's point of view (Pramling Samuelsson \& Johansson, 2006).

The idea of play and learning was supported when the children in group 3 were asked how playing puzzles helps them to learn. Amy said that playing puzzles helps you get smart and learn how to put things together. Samuelsson and Carlsson (2008) explain that when children talk about play and learning, there are many similarities in the thoughts they share, and they describe both play and learning as activities that are joyful and transformative. In Ontario's kindergarten document (Ontario Ministry of Education, 2016), play is described as a vehicle for learning, and play and academic work are inextricably linked for children. The statement on play-based learning released by the Council of Ministers of Education in Canada (2014) explains that play paves the way for learning because it nourishes every aspect of children's development, from intellectual skills to social, emotional, and physical skills. Additionally, Mastrangelo (2017) emphasizes that researchers have discovered that the experience of play actually changes the connections of the neurons in the prefrontal cortex, and that without play experiences, those neurons remain the same. It is those changes in the prefrontal cortex during childhood that help wire up the brain's executive control centre, which has a critical role in regulating emotions, making plans, and solving problems (Pellis \& Pellis, 2014).

A narrative that supports the idea of pretend play was revealed when the children made real-life connections about how their classroom can help them learn to become different people in the community. In the building centre, the children talked about how if they practice building they could become builders or learn how to build a house (see Figure 1).

Researcher: What about this one. What is this?

Shannon: Building. I like building because you get to learn how to build stuff, and soon if you practice so much you might be able to build a house. 


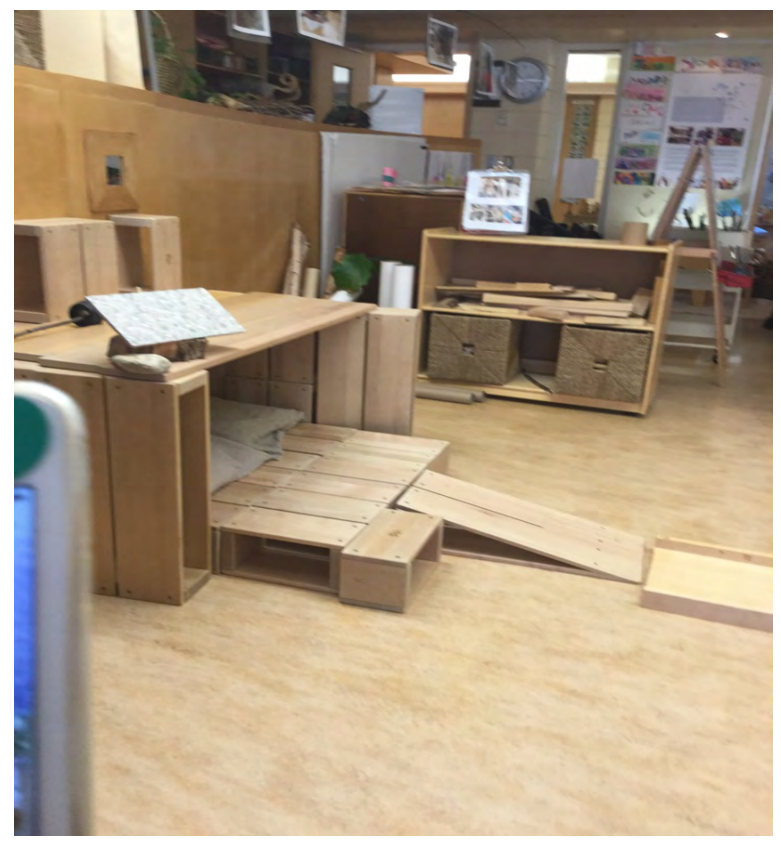

Figure 1. Shannon's photograph of the building centre.

In the art centre, Mandy talked about how she was learning to become a kid artist by practicing her poses. In drama, the children said that they can learn how to be a parent and discussed the work that is involved. Vygotsky (1967) supports the idea of real-life connections in play and explains that, "as play develops, we see a movement toward the conscious realization of its purpose" (p. 17). He explains that play is a "recollection" of a situation witnessed by children that sparks their imagination and ultimately influences their play. The children also discussed how talking and working with their peers in the classroom environment helps them to learn (see Figure 2). Mandy talked about how you can talk to one another while working at the communication centre.

Researcher: Tell me about this picture.

Mandy: It's communication, where we draw stuff and make stuff. Different things. We talk to each other and we make different things.



Figure 2. Mandy's photograph of the communication centre. 
Olivia explained that you get to meet new people while you are working at the light centre (see Figure 3).

Olivia: That one is light.

Researcher: What happens in light?

Olivia: I took a picture of Andrea pretending that was my cake.

Researcher: Any more about light that helps you to learn?

Olivia: I get to see new people working light and I was in that centre with Amy.

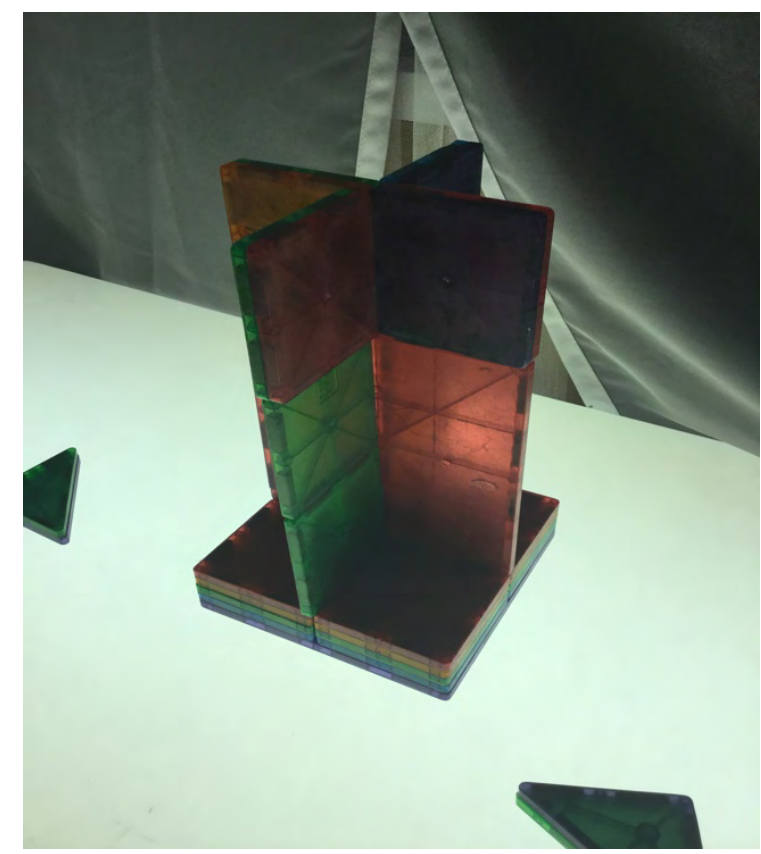

Figure 3. Olivia's photograph of the light centre.

Michelle remarked that when you are in the light centre, people often come to see what you are doing.

Researcher: So, tell me about light. What can you learn in light?

Michelle: People often come to the see light centre to see what they are doing.

Researcher: What can you learn?

Michelle: We learn about how we play games in there.

Malaguzzi, in conversation with Gandini (2011b), discusses the importance of building relationships and explains that it helps children build autonomy and understand that they are individuals part of a larger group.

The children also spoke about how the documentation on the walls of their classroom helps them learn. Melissa and Zoe took pictures of the books the children made that were displayed on the wall in the communication centre (see Figure 4). Zoe explained that the books were written by her peers and were about their research. Malaguzzi, in conversation with Gandini (2011a), explains that the walls of Reggio schools "speak and document" and can be used by children to revisit and expand on their previous learning experiences. 


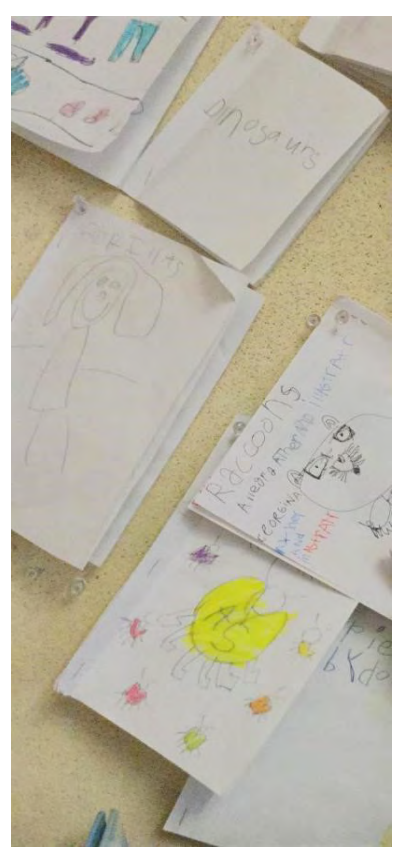

Figure 4. Photograph of child-made books displayed on the wall in the communication centre.

\section{Scope and Limitations of the Study}

The purposes of this study were to explore the concept of the environment as a third teacher, to document children's views on their learning environment, and to unravel how the environment sparks children's natural learning curiosity. A major limitation of this study was the large size of the focus groups. The children were divided into what appeared to be manageable groups of four; however, the focus groups were too large and participants were unable to address all of the photos within the allotted timeframe, resulting in a shortened discussion and quick analysis. Perhaps groups of two or three children would have spurred a richer discussion and would have provided more time for each group member to contribute. The daily schedule only allowed for three research visits. A total of five and half hours was spent in the classroom observing the children and conducting the focus groups during each of the three research visits. Although the study adopted the mosaic approach (Moss \& Clark, 2011) for listening and responding to children, there was insufficient time allotted by school staff to engage in deeper conversations and provocations about the children's photographs. Parkinson (2001) explains that when working with young children, small groups are necessary because children spend most of their day interacting with small groups of children. To interview children in context, one needs to ensure that a social setting that supports their memory is being provided. While waiting for their peers to examine and discuss their photographs, the children became restless. Due to the restlessness of the children, some of them chose to leave the focus groups early, thus limiting the amount of group discussion. Their restlessness also limited the discussion because the children only discussed the photos they took. It would have been interesting to hear the children reflect on and comment about one another's photographs. Douglas (2009) explains that practical concerns can limit the amount that can be measured during a study. Furthermore, since this particular Reggio-inspired school is for girls only, differences in responses between genders could not be investigated. Although a same-sex school limits the variety of data collected in research, Mael (1998) explains that single-sex schooling leads to higher academic achievement and educational aspirations, especially for girls. 


\section{Summary}

By employing a phenomenological approach to this qualitative study that involved children as co-researchers, the study was able to give voice to children in research. This research study explored 16 children's ideas about how they perceive their learning environment and the environment's ability to help them learn. The children were given voice in this study by having them first photograph the areas in their classroom that they believed helped them to learn. Then, the photos were used to spark a discussion during the photo interview analysis stage within small focus groups. After careful analysis, we determined that the children in this study perceived their environment as a place that helped them learn and therefore acted as a third teacher. The math centre was the most photographed area of the classroom, followed by the communication and building centres, the art centre, the light centre, and the drama centre. The children described how, within the centres, they were able to learn by using the materials provided, engaging in imaginative or pretend play, making real-life connections, communicating with their peers, and exploring the documentation on the walls of their classroom. The following themes summarize what the children expressed as important to their learning: learning centres, materials, pretend play, communication, and documentation. Each of these is discussed below.

Learning centres. During the focus groups, the children referred to the different learning centres within the classroom when discussing how different areas help them to learn. The children view the learning centres and the other identified areas within the classroom as important places that help them to learn.

Materials. The children explained that the materials located at the various learning centres supported and enhanced their learning experiences. The children identified a wide array of materials within the learning centres and how they manipulated the materials to help them learn. For example, in the math centre, the children highlighted the hundreds chart as an item that helps them to learn how to count by different intervals.

Pretend play. Pretend play was seen as a learning experience by most of the children, yet some of the children did not make the connection between play and learning. The children identified many different play experiences they had at the various learning centres (e.g., playing family in the drama centre and building structures like boats, houses, and castles in the building centre). The children also connected their pretend play with real-life learning experiences. They explained that when at the building centre they can learn to become a builder and build a house one day when they are older and while in the drama centre they can learn to be a parent while playing family. These are poignant examples of learning through play.

Communication. The children expressed the importance of communication in their classroom as part of their learning process and cited talking and working with their peers as an example. They explained that while working at the different centres, they were able to talk to the other children in the centre and also had the opportunity to share their work with the whole class. The reciprocal nature of conversations taking place in the centres supports the importance of building relationships during the learning process.

Documentation. The children confirmed that the Reggio idea of documentation on the walls aids in the learning process by allowing them to revisit and expand on their previous learning opportunities. The children photographed the research books they created that were displayed on the walls in the communication centre. They explained that they developed the books based on their own research while working in the centre.

Through classroom observation and interpretation and analysis of the children's responses during the focus groups, the learning environment explored in this study supports all of Fraser's (2012) eight principles in determining whether the environment acts as a third teacher. Lastly, the research results were shared with the children in this study through the creation of a photo scrapbook that included quotations they shared in the focus groups. The 
scrapbook was gifted to the children in this senior kindergarten class as a way to thank them for their participation throughout the research process. The book was also created as a conduit for the children to explore the findings because the published research would not be in an accessible format for them.

\section{Conclusion}

Epstein (2003) reminds us that there is empirical and practical evidence that the development of thinking and reasoning in children can be promoted by having them reflect on and consider what they are doing and what they are learning. This research study set out to explore children's ideas and perspectives about their learning environment and how it helps them to learn. Although the study lacked an in-depth reciprocal conversation through questioning and responding, the data that was collected confirmed that the children believed their classroom environment helped them to learn. A deeper exploration of concepts would have been possible if there had been greater time allotted in the classroom setting for conducting this research. Additionally, greater time would have also allowed for further follow-up questions to children's responses, and perhaps would have given them a space to more deeply and critically analyze their photos and ideas. Epstein (2003) explains that children between the ages of 3 and 6 years are able to make careful observations about their environment. The children in this study were able to effectively reflect on their environment and identify areas they believe help them to learn.

\section{References}

Arseven, A. (2014). The Reggio Emilia approach and the curriculum development process. International Journal of Academic Research, 6(1), 166-171. doi: 10.7813/2075-4124.2014/6-1/B.23

Becker, K., \& Mastrangelo, S. (2017). Ontario's early learning kindergarten program: A transformative early childhood education initiative. Young Children, 72(4). Retrieved from https://www.naeyc.org/resources/pubs/yc/sep2017/ontario’s-early-learning-kindergarten

Bronfenbrenner, U. (1979). The ecology of human development: Experiments by nature and design. Cambridge, MA: Harvard University Press.

Callaghan, K. (2013). The environment is a teacher. Queen's Printer for Ontario. Retrieved from http://www.edu.gov.on.ca/childcare/ Callaghan.pdf

Clark, A. (2007). A hundred ways of listening: Gathering children's perspectives of their early childhood environment. Young Children, 62(3), 76-81.

Cook-Sather, A. (2002). Authorizing students' perspectives: Toward trust, dialogue, and change in education. Educational Researcher, 31(4), 3-14. doi: 10.3102/0013189X031004003

Council of Ministers of Education of Canada. (2014). CMEC statement on play-based learning. Retrieved from https://www.cmec.ca/ Publications/Lists/Publications/Attachments/282/play-based-learning_statement_EN.pdf

Darragh, J. C. (2006). The environment as the third teacher. (ERIC Document Reproduction Service No. ED493517. Retrieved from http:// files.eric.ed.gov.ezproxy.library.yorku.ca/fulltext/ED493517.pdf

Dodd-Nufrio, A. T. (2011). Reggio Emilia, Maria Montessori, and John Dewey: Dispelling teachers' misconceptions and understanding theoretical foundations. Early Childhood Education Journal, 39(4), 235-237. doi: 10.1007/s10643-011-0451-3

Douglas, K. (2009). Sharpening our focus in measuring classroom instruction. Educational Researcher, 38(7), 518-521. doi: 10.3102/0013189X09350881

Drew, E. D., Olsen, M., \& Pichierri, M. (2000). How to create a reusable resource center: A guidebook for champions. Melbourne, FL: Institute for Self Active Education.

Drew, W. F., \& Rankin, B. (2004). Promoting creativity for life using open-ended materials. Young Children, 4, 38-45. 
Edwards, C., Gandini, L., \& Forman, G. (Eds.). (2011). The hundred languages of children: The Reggio Emilia experience in transformation. Santa Barbara, CA: ABC-CLIO.

Einarsdottir, J. (2005). We can decide what to play! Children's perception of quality in an Icelandic playschool. Early Education \& Development, 16, 469-488. doi: 10.1207/s15566935eed1604_7

Epstein, A. S. (2003). How planning and reflection develop young children's thinking skills. Young Children, 58(5), 28-36.

Fraser, S. (2012). Authentic childhood: Exploring Reggio Emilia in the classroom. Toronto, ON: Nelson Education.

Gandini, L. (2011a). Connecting through caring and learning spaces. In C. Edwards, L. Gandini, \& G. Forman (Eds.), The hundred languages of children: The Reggio Emilia experience in transformation (pp. 317-341). Santa Barbara, CA: ABC-CLIO.

Gandini, L. (2011b). History, ideas, and basic philosophy. In C. Edwards, L. Gandini, \& G. Forman (Eds.), The hundred languages of children: The Reggio Emilia experience in transformation (pp. 27-72). Santa Barbara, CA: ABC-CLIO.

Greig, A. D., Taylor, J., \& MacKay, T. (2012). Doing research with children: A practical guide. Thousand Oaks, CA: SAGE.

Grover, S. (2004). Why won't they listen to us? On giving power and voice to children participating in social research. Childhood, 11(1), 81-93. doi: $10.1177 / 0907568204040186$

Harcourt, D., Perry, B., \& Waller, T. (Eds.). (2011). Researching young children's perspectives: Debating the ethics and dilemmas of educational research with children. Abingdon, UK: Taylor \& Francis.

Hewes, J. (2006). Let the children play: Nature's answer to early learning. U.S. Department of Health and Human Services, Early Childhood Learning Knowledge Centre.

Hewett, V. M. (2001). Examining the Reggio Emilia approach to early childhood education. Early Childhood Education Journal, 29(2), 95-100. doi: 10.1023/A:1012520828095

Johnson, B., \& Christensen, L. (2012). Educational research: Quantitative, qualitative, and mixed approaches ( (th $^{\text {th }}$ ed.). Thousand Oaks, CA: SAGE.

Kangas, M. (2010). Finnish children's views on the ideal school and learning environment. Learning Environments Research, 13(3), 205223.

Katz, L. G. (1987). What should young children be learning? Child Care Information Exchange, 11(94), 23-25. Retrieved from https:// portal.ddsb.ca/class/qssiogv/Lists/HandoutsandMaterials/What\%20should\%20children\%20be\%20learning.pdf

Klefstad, J. M. (2015). Focus on family: Environments that foster inquiry and critical thinking in young children: Supporting children's natural curiosity. Childhood Education, 91(2), 147-149. doi: 10.1080/00094056.2015.1018795

Lansdown, G. (2004). Participation and young children. Early Childhood Matters, 103, 4-14.

Lansdown, G. (2011). Every child's right to be heard: A resource guide on the UN Committee on the Rights of the Child General Comment No. 12. London, UK: Save the Children \& United Nations Children's Fund.

Mael, F. A. (1998). Single-sex and coeducational schooling: Relationships to socioemotional and academic development. Review of Educational Research, 68(2), 101-129. doi: 10.3102/00346543068002101

Makin, L. (2003). Creating positive literacy learning environments in early childhood. In N. Hall, J. Larson, \& J. Marsh (Eds.), Handbook of early childhood literacy (pp. 327-337). doi: 10.4135/9781848608207.n27

Mastrangelo, S. (2017). The promise of play as an intervention to develop self-regulation in children on the autism spectrum. In T. Bruce, P. Hakkarainen, \& M. Bredikyte (Eds.), The Routledge international handbook of early childhood play (pp. 376-394). New York, NY: Routledge.

Montandon,C., \& Osiek, F. (1998).Children'sperspectives on their education.Childhood, 5(3),247-263.doi: 10.1177/0907568298005003002 
Moss, P., \& Clark, A. (2011). Listening to young children: The mosaic approach. London, UK: Jessica Kingsley.

New, R. S. (1998). Theory and praxis in Reggio Emilia: They know what they are. In C. Edwards, L. Gandini, \& G. Forman (Eds.), The hundred languages of children: The Reggio Emilia approach-Advanced reflections (pp. 261-284). Westport, CT: Greenwood.

Ontario Ministry of Education. (2014). How does learning happen? Ontario's pedagogy for the early years. Retrieved from http://www.edu. gov.on.ca/childcare/HowLearningHappens.pdf

Ontario Ministry of Education. (2016). The kindergarten program. Retrieved from https://files.ontario.ca/books/edu_the_kindergarten_ program_english_aoda_web_oct7.pdf

Parkinson, D. D. (2001). Securing trustworthy data from an interview situation with young children: Six integrated interview strategies. Child Study Journal, 31(3), 137-155.

Pellis, S. M., \& Pellis, V. C. (2014). Play and the socially competent brain. Interaction, 28, 20.

Pinter, A., \& Zandian, S. (2015). "I thought it would be tiny little one phrase that we said, in a huge big pile of papers": Children's reflections on their involvement in participatory research. Qualitative Research, 15(2), 235-250.

Pramling Samuelsson, I., \& Johansson, E. (2006). Play and learning: Inseparable dimensions in preschool practice. Early Child Development and Care, 176(1), 47-65.

Pyle, A. (2013). Engaging young children in research through photo elicitation. Early Child Development \& Care, 183(11), $1544-1558$. doi: 10.1080/03004430.2012.733944

Rinaldi, C. (2001). Reggio Emilia: The image of the child and the child's environment as a fundamental principle. In L. Gandini \& C. P. Edwards (Eds.), Bambini: The Italian approach to infant/toddler care (pp. 49-54). New York, NY: Teachers College Press.

Samuelsson, I. P., \& Carlsson, M. A. (2008). The playing learning child: Towards a pedagogy of early childhood. Scandinavian Journal of Educational Research, 52(6), 623-641. doi: 10.1080/00313830802497265

Schiller, W., \& Einarsdottir, J. (2009). Listening to young children's voices in research: Changing perspectives, changing relationships. [special issue] Early Child Development and Care, 179(2), 125-130. doi: 10.1080/03004430802666932

Shenk, D. (2010). The genius in all of us. New York, NY: Doubleday.

Shipley, D. (2008). Empowering children. Play-based curriculum for lifelong learning (4 $4^{\text {th }}$ ed.). Toronto, ON: Nelson Education.

Smith, A., Duncan, J., \& Marshall, K. (2005). Children's perspectives on their learning: Exploring methods. Early Child Development and Care, 175, 473-487. doi: 10.1080/03004430500131270

Steglin, D. A. (2005). Making the case for play policy: Research-based reasons to support play-based environments. Young Children, 60(2), 76-86.

Stephenson, A. (2009). Horses in the sandpit: Photography, prolonged involvement and "stepping back" as strategies for listening to children's voices. Early Child Development and Care, 179(2), 131-141. doi: 10.1080/03004430802667047

Strong-Wilson, T., \& Ellis, J. (2007). Children and place: Reggio Emilia's environment as third teacher. Theory into Practice, 46(1), 40-47. doi: $10.1080 / 00405840709336547$

Sylva, K., Siraj-Blatchford, I., Taggart, B., Sammons, P., Melhuish, E., Elliot, K., \& Totsika, V. (2006). Capturing quality in early childhood through environmental rating scales. Early Childhood Research Quarterly, 21(1), 76-92. doi: 10.1016/j.ecresq.2006.01.003

UNICEF. (2014). Convention on the rights of the child: Rights under the convention on the rights of the child. Retrieved from http:// www.unicef.org/crc/index_30228.html

Vygotsky, L. S. (1967). Play and its role in the mental development of the child. Soviet Psychology, 5(3), 6-18. doi: 10.2753/rpo1061040505036

Wexler, A. (2004). A theory for living: Walking with Reggio Emilia. Art Education, 57(6), 13-19. doi: 10.2307/27696039 